\title{
A Socio-political Analysis of Pentecostalism and Political Passivity in Zimbabwe
}

\section{Henerieta Mgovo}

\begin{abstract}
Religion, particularly Pentecostalism, has proved to be fertile ground for the expression of gullible behaviour. The research argues that religious leaders in Zimbabwe have a hand in the political passivity of Zimbabweans. This article is an analysis of how Pentecostal interpretations of the Book of Romans have led to teachings that have made Zimbabweans politically passive and become a hindrance to political contestations. The research adopted a qualitative approach and a case study focusing on the Zimbabwe Assemblies of God Africa Forward in Faith (ZAOGA FIF). The research observes that Pentecostalism promotes political passivity as it focuses on the literal interpretation of Romans 13: 1-7, and calls for unquestionable reverence to political leaders as they do to their Charismatic Pentecostal Church leaders. This has greatly impacted on the political life of many Pentecostal Church members who have not been able to protest against any political maladministration, be it in the Church or government. In conclusion, the research recommends that Pentecostal adherents must resist the gullible Pentecostal teachings and be sceptical of some of the messages delivered by charismatic leaders.
\end{abstract}

Keywords: Pentecostalism, gullibility, political passivity, political contestations.

\section{Introduction}

Over the centuries, Christianity has been integrally related to the social and political development of most Zimbabwean citizens. It is inevitable that the Church's worldview may greatly influence the manner in which adherents 
perceive or even address administrative issues in both religious and secular spheres. The Church may represent a means of coping with adverse situations, rebelling against political domination or passive acceptance of the status quo. The rise of Pentecostalism in Zimbabwe has also brought with it challenges in the area of political contestations, as it has tended to turn adherents into gullible consumers of literal interpretations of certain Biblical scriptures. This article focuses on Romans 13: 1-7 as one such scripture that is a politically-inflected text that has been used by Churches to justify and support dictatorial and undemocratic practices in many countries, including Zimbabwe. In this respect, the article seeks to establish the extent to which Pentecostal Biblical interpretation of Romans13: 1-7 and the unquestionable reverence of Charismatic Church leaders as God's ordained mouthpieces have brought gullibility in the area of political contestations. The article presents an exegesis of Romans 13: 1-7 and demonstrates how Pentecostal literal interpretation of the same has turned Pentecostal Church members into political passivity. To achieve this aim, the author employs the New Testament socio-political method of conceptual analysis. It also draws inferences from primary research conducted by other scholars.

The research acknowledges that Pentecostal Churches are not a united group. They are divided organizationally, socially and theologically. This division has bearing on their engagement, or lack of it, in political affairs in Zimbabwe, giving rise to many different and mutually contradictory forms of Pentecostal views of political establishments. Pentecostal leaders and their followers seem to be ambivalent in their participation in political activities. In Zimbabwe and many other nations, Pentecostalism is the biggest Christian conversion, which claims large mass following. However, the impact of Pentecostalism in politics is still minimal. In this regard, Togarasei (2013: 106) argues that, despite the large numbers and the respect for leadership, Pentecostals have proved '. ... easy to use as pawns in the hands of politicians'. This is, according to Togarasei (2013), a case of gullibility. Hence, Togarasei maintains that it is time to start thinking about ways of waking up many Pentecostal followers from their political slumber. Furthermore, Freston (2014: 1) echoes the same sentiments by pointing out that all over the world Pente-costalism has reached unprecedented levels of social visibility and that, for that very reason, it has to be transformed into a political trampoline. This is to say, since Pentecostalism has reached the public sphere with great vibrancy, it has to instil confidence in its followers to be able to take part in political contestations.

This article is divided into four sections. The first section defines Pen- 
tecostalism and gullibility. The second section focuses on literal and exegetical interpretations of Romans 13: 1-7. Section three delves into the impact of Pentecostalism on the adherents' political consciousness and goes on to analyse the problems Pentecostalism creates in matters of political contestations. The article ends with a fourth section which provides findings, some recommendations and a conclusion.

\section{Methodology}

The study utilised a qualitative research approach. According to Creswell (2014: 4), qualitative research is an approach for exploring and understanding the meaning individuals or groups ascribe to a social or a human problem. Therefore, the qualitative research approach is suitable to deal with the human problem of religious gullibility being explored in this article. The study uses both primary and secondary sources. The hermeneutical and exegetical methods of reviewing scriptural relevance in relation to the role of the Church in politics are employed. Some data were also collected through desk research and face-to-face interviews with selected Pentecostal Church followers. The study has taken into consideration the core fundamentals of ethical practices regarding consent, anonymity and confidentiality.

\section{Theoretical Framework}

The research is underpinned by Karl Marx's philosophy of religion (Lobkowicz 1964). Marx (1884) was of the opinion that religion is the opium of the people from which people get solace and comfort from their troubles or sufferings. In his critique of Hegel's book, Philosophy of Right Standing, McKinnon (2005: 1-2) maintains that 'Religion is the sigh of the oppressed creature, the heart of the heartless world, just as it is the spirit of the spiritless situation'. The implication is that, although religion gives moral support as well as counselling services to the followers, it also helps to mould and influence people to accept their situation without complaint. This is what this article refers to as gullibility in the context of political consciousness.

Based on the Marxist Philosophy of Religion, the article observes that the consequences of religious passivity are that religion can lull the followers into subservience so that they accept their leaders as God-given or natural. Therefore, this theory is the most suitable as the basis of an exploration of the place of religion in the political passivity of Pentecostal Church followers. 


\section{Defining Terms \\ Pentecostalism}

Pentecostalism is understood as a renewal movement within Christianity. It places extraordinary emphasis on individual experiences of the Creator or God through the baptism by the Holy Spirit. Pentecostalism has become a global Christian revivalist and missionary movement that places the transcendent workings of the Holy Spirit and charismatic practices such as the spiritual gifts of healing, speaking in tongues or glossolalia and prophecy (according to Acts 3 and 1 Cor. 12-14), at the centre of its activities. Anderson (2004: 17) defines Pentecostalism as:

... divergent African churches that emphasise the working of the spirit in the church, particularly with ecstatic phenomena like prophecy and speaking in tongues, healing and exorcism. The key characteristics of Pentecostal churches are speaking in tongues, performing of miracles, healing, prophesy and the preaching of the gospel of prosperity. Aspects of Pentecostalism include the purported move of God, usually noted through people rolling on the floor, hysterical activity, exorcisms (demon casting/screaming), miracles, claims of healings, interpretation of visions and dreams, and the association of every negativity with evil or satanic spirits.

The term 'Pentecostal' is taken from the account of the coming of the Holy Spirit in Acts 2: 1-13 (Anderson 2010). The followers of Jesus Christ were 'filled' with the Holy Spirit and began speaking in other tongues in the Upper Room in Jerusalem (Acts 2:1-13), which is one of the views of how the church was founded (Clifton 2009; Stanley 2007). Most Pentecostal activities are traced back to Topeka Kansas on 1 January 1901 under Charles Perham, and the Azusa Street, Los Angeles in April 1906 under William Seymour (Anderson 2010). Men and women replicated the acts of the First-Century apostles: speaking in tongues, healing the sick and prophesying (Miller \& Tetsunao 2007). Therefore, the New Testament is important as a source on which Pentecostal Churches base their foundation.

In recent years, Zimbabwe has witnessed tremendous Pentecostalism, particularly after the 1990s. Some of the Pentecostal Churches are locally initiated by Africans without any relation with mission Pentecostal Churches abroad. They are self-financing, self-governing and self-supporting. In outlook, all Pentecostal Churches proclaim a pragmatic gospel that seeks to 
address practical issues of poverty, unemployment, sickness and evil spirits (Friedrick 2017). Pentecostal leaders avoid direct political engagement and contestations with the state and are often accused of unquestionably or gullibly supporting the status quo. Their political acquiescence is partly due to their theological interpretation of Romans 13: 1-7, which calls for obedience to those in authority, as they are ordained by God. In this case, Pentecostal Churches' political philosophy becomes profoundly ambivalent. Therefore, Pentecostalism in this study refers to those African Churches that emphasise the centrality of Holy Spirit in faith and in practice.

\section{Gullibility}

Gullibility is generally understood in various ways, ranging from outright stupidity to indecision raised by the epistemic indeterminacy of the testimony of others. The activities of tricksters fall within this range. These activities happen in almost every scope of life, be it business, religion, law or politics. The preachers sway people into believing that they have something to offer. As a result, people throw caution out of the window and follow them. Those who claim to have direct contact with God tend to have an edge over those who do not have direct access to God. It is in such contexts that religious imposters arise and many people are wavered into believing them sheepishly. It is against this backdrop that some end up being cheated. Often this tendency is labelled gullibility. If gullibility is understood as a belief in something with no substantiating facts, does this make the affected persons foolish? Believing that another person is endowed with special gifts from God, which can help them, is not unwarranted, but taking what the person says uncritically can be irrational and hence gullible. In this article we seek to unpack the concept of 'religious gullibility' in relation to political passivity in Zimbabwe.

Chimuka (2017) infers that 'gullibility' is the unwarranted belief in something with no substantiating facts to support it. In this, gullibility is failure of social intelligence, where a person is easily tricked or manipulated into an ill-advised course of action. Greenspan (2009) suggests the existence of a distinction between credulity (an uncritical acceptance of information presented) and gullibility (a tendency to be tricked or manipulated). Therefore, credulity is merely 'a belief' and gullibility is the behaviour or concrete action aspect. Hence one may manipulate a potential victim's credulity in order to have them perform a gullible action (Teunisse 2015, in Greenspan, Loughlin \& Black 2001). 
Kourken Michaelian (2010) refers to gullibility as blind trust; that is, trusting without questioning. The question is, how much should one trust the testimony of another in the absence of compelling evidence? Should one be radically sceptical and not believe anything, which presents itself with no undefeated evidence, even when it comes from the mouth of someone who speaks on behalf of God? Is it possible to question Pentecostal Charismatics leaders who are believed to be God's mouthpieces to humanity if they purport to speak what they proclaim to be the will of God and back their utterance with a Biblical basis such as Romans 13: 1-7? Will one not be labelled as a heretic if he or she questions Biblical texts and renowned inspired preachers?

In the African traditional context and unlike in the Christian context, Chimuka (2017) singles out examples of folktales that were meant to warn children or listeners against falling victim to tricksters. Listeners to the folktales who were, particularly children, were cautioned against taking what was said by others as true in all cases. The lessons drawn from the folktales warned children not to take anything at face value, particularly from characters who were morally suspect and particularly dangerous. However, the question with which the study wrestles pertains to whether pastors, bishops and elders can be categorised as morally suspect or dangerous preachers in the context of Biblical interpretation and giving political guidance to followers. These people deserve respect from the public, to such extent that if they turn out to be tricksters, they will mislead many. If they fail to interpret a Biblical text properly, they sway the congregants who trust them as God's mouthpieces.

Accordingly, the study focuses on Pentecostal Christians as prone to naivety or gullibility, as they tend to believe everything they hear from their leaders without questioning it. In this respect, they can easily fall prey to being tricked. To what extent can Pentecostal followers question the credibility of one who purports to be under the influence of the Holy Spirit and still remain faithful followers of Christ? Trusting others, especially trusting Pentecostal Charismatic leaders in their scriptural interpretation under the influence of the Holy Spirit, is the most common practice among Pentecostal Christians (Origgi 2008: 36). However, because of this trust, Pentecostal Christians fall prey to political tricksters. Greenspan (in Chimuka 2017), says that gullibility is not generally seen as an affliction; yet it can do terrible harm, as evidenced in losing one's life-savings to a swindler, falling in love with a sweet-talking scoundrel, or putting one's life into the hands of a cruel political leader. The article does not intend to deal with gullibility in all its facets, but specifically with Pentecostalism and political gullibility evidenced in political passivity. 


\section{Role of Leadership in Pentecostal Churches}

Pastors, bishops and elders are very influential people in Church circles and their attitudes are likely to rub of onto their followers. This implies that even the political position of the leader becomes that for the followers without them questioning this. This implies that Pentecostal leaders can easily exploit this reverence to influence their followers for either political passivity or political transformation. They can profoundly shape the thinking and behaviour of their members. Shafranske (1996) also highlights that it is the groups of people that individuals are closely affiliated to that influence their worldviews the most. According to Galanter in Shafranske (1996), a charismatic leader's influence within a church group establishes the validation of the beliefs within the sect, often within the exclusive control of the leader. The leader often has the ability to inspire hope or fear, combined with a dynamic presence. This is an important aspect of the leader's authority and influence in the formation and maintenance of the charismatic group.

Taylor et al. (2000) remind us that dealing with social, religious and political problems was the domain of religious leaders and communities for many centuries prior to the advent of modern secular structures. Religious leaders are still deemed important by many people, even politicians themselves. In Pentecostal Churches, therefore, it can be said that considerable political influence is located within the person of the charismatic leader. The Charismatic leader; that is, prophets, pastors, bishops and archbishops, are sometimes the first and only people that individuals encounter when in need. They often function as gatekeepers to social, political and health services (Taylor et al. 2000). They are typically approached directly by Pentecostal followers in spiritual, economic, social and political matters. As a consequence, Charismatic leadership positions are important ones with respect to the political decisions of their congregants. Therefore it must not be underestimated.

Pentecostalism and political gullibility are evidenced in the political passivity of most Christians. The research wonders why such a large and influential body has not had a strong voice in the country on issues affecting the people's freedom. According to Young (2010), Pentecostal churches seem to be convinced that the task of the Church is primarily spiritual and they base this on Romans 13: 1-7 which they preach from a literal interpretation. Since politics is about governance of the all people, regardless of religious or political affiliation, Pentecostalism needs to stop interfering with the people's political consciousness. Young (2010: 3) alludes that Pentecostal churches cannot 
afford to be silent in addressing socio-political challenges of the country as if they are not affected.

\section{A Literal Interpretation of Romans 13: 1-7}

A literal Biblical interpretation is often used as a pejorative to describe or ridicule the interpretative approaches of fundamentalist or evangelical Christians. According to Recanati (2004), literal interpretation means interpreting words in their usual or most basic sense without metaphor or allegory. Literal interpretation is often necessarily associated with the belief in verbal plenary inspiration according to which not only the Biblical message, but also the individual words in which that message was delivered or written down were divinely disclosed. This was the long-held interpretation of Romans 13:1-7 that acts as the biblical basis for corporal punishment.

Tshuma (2017: 229) argues that Romans 13: 1-7 has been misconstrued to imply a blind endorsement and support of all those in authority, like the appeasement drive by the Zimbabwe Council of Churches (ZCC) during the election violence of 2008, when it indicated that:

We are not anti-Government; we will not condemn our leaders just because the imperialist West wants us to do so .... We are a Church body and we need to support our leaders and pray for them and not insult them.

One possible context of Romans 13: 1-7, as interpreted by scholars of Romans, was an acknowledgement of the peace and stability that was achieved during that time; hence the need to back up the stability with prayers. Misguided claims, such as emphasising that Christians are to be in the world, but are not of this world, need to be unpacked for the purposes of clarity. The salvation gospel, which is futuristic, tends to pacify Pentecostals and limit them to the pulpit gospel, surrendering all to God with mere intercessory prayers.

Tshuma (2017) further contends that politicians have a tendency to reduce Christians to the opening and closing prayers during conferences and/or national gatherings, while leaving the 'important issues' on the table for political elites. Politicians attend church services largely for 'political convenience' but Christians are threatened not to cross the line into the political domain. This is an inherently contradictory relationship bent on subordinating the mission of the church. According to Mtata, quoted verbally at The Zimbabwe Council of 
Churches conference in 2018, ' $\ldots$ in a situation of injustice, the role of the Church is to identify with the poor and the voiceless and to give them support in their struggle for freedom, justice and dignity'. Combating political injustices and advocating for the poor will mean Christian political involvement of one sort or the other. Not every Christian will take the same approach or be called to the same political stance, or even the same political conclusions. Some will write letters to politicians (e.g. the ZCC Pastoral Letters, The Zimbabwe We Want document), while others might teach voter education and observe elections (Ecumenical Peace Observation Initiative). Others will launch prophetic protests, like during the Pentecost Conference in Harare (1992), when Guti rebuked some of the leaders of the nation for shedding innocent blood, and the mysterious disappearance of people (Guti 1994: 105), which is a very progressive contribution coming as a lone voice from a Pentecostal leader during those politically uncertain times. Others may sit at a political discussion table and try to 'be the Daniels', like the Ecumenical Peace Observation Initiative in Zimbabwe (EPOIZ). Others will march around the city in spiritual warfare and intercession for the sins of the city, while others may run for political posts.

\section{Exegetical Interpretation of Romans 13: 1-7}

Exegesis, from Greek word Exegomai which means (to lead out), is a critical explanation or interpretation of a Biblical text, particularly a religious text (Hayes \& Holladay 2007). Exegesis aims to provide a standardized, scholarly and critical interpretation and explanation of a written text. Its purpose is to present a case for how the original author intended his/ her text to be understood by using a methodology that incorporates many vital considerations. Exegesis is important to Biblical scholars because it allows the researcher to critically interpret and attempt to explain the meaning of the biblical text and be rigorously accountable for that interpretation. Exegesis provides modern persons and evidence based scholarly approach to reading the bible. This method is the one that will be used in interpreting Romans 13: 1-7 (Hayes \& Holladay 2007).

Hermeneutics, according to Osborne (1992), is both a science and an art involving logically orderly classification of the law of interpretation on one hand and an acquired skill demanding both imagination and ability to apply those laws of interpretation on the other. This art and science will be applied in the interpretation of Romans 13: 1-7. 


\section{The Historical Political Setting of Romans 13: 1-7}

Marcus Borg (2002) contends that the letter to the Romans was written in A.D. 57 when Nero was in power, but in the early part of his reign (A.D. 54-68). There appears to be no indication that at that time he was a tyrant and brutal ruler. The Jews had been expelled in A.D. 49, but that was under Claudius and things appeared to be different in A.D. 57. There was a problem with 'tax protests' under Nero in A.D 58, but this does not appear to be relevant at the time of the writing of Romans. Therefore, the study assumes that political conditions were fairly stable and that the Christian Church which was undoubtedly born in the Synagogue at Rome enjoyed the status of religio licita (lawful/ permitted or legitimate religion) as they were still largely seen to be within Judaism's fold. Kasemann (1980) suggests another possibility for the background to the passage. He claims that certain Christian enthusiasts had thrown off all restraints in the light of their heavenly calling and regarded 'earthly authorities' with indifference or contempt. This may be true, but it is difficult to defend from within or outside of the passage. Indeed, the use of the indicative 'you pay taxes' (v. 6) would tend to indicate that there was at least some degree of submission to the state already in the Church. Paul exhorts the Romans in right conduct toward the state but it is very difficult to say for sure what prompted such a decision.

Romans 13: 1-7 has often been used as a blue print for church state relations by both Christian and non-Christians alike. The question is as Christians: Should we meddle in politics? Is politics for the politicians? In his response to these questions, Dr Aynos Moyo, quoted ippisisma verba (quoted verbatim) when he was questioned on what Paul meant by the phrase 'Government is appointed by God'. He articulated that Paul was apocalyptically inspired, as he thought the world was coming to an end. Paul was optimistic about the state and he thought that the Roman Empire was the good thing given to the people. Dr Moyo further highlighted that Paul could have changed his mind, had he lived up to the era of persecution. He could, instead, have demonized the State. However, he reiterated that the State is necessary to regulate order and peace for the good of humanity, but where is the role of the Church?

The Church is the watchdog; it must make sure that the State fulfils its mandate of protecting the country from outside invasion and deliver goods and services. Tshuma (2017: 225) argues that Church and State are independent and autonomous in their own spheres, but are at the service of humanity. The engagement between politics and the Church should be that of provision of 
checks and balances for both parties. Hence, Pentecostal Churches in Zimbabwean society cannot afford to be indifferent or reduced to prayers and offering guidance on moral issues, which is a rather narrow interpretation of its broadbased mission. The question is, should the Christians in this case consign themselves to the pulpit and allow the politicians to do whatever they want with the country? Is the church's duty to preach and spectate saying thus not our domain; ours is the salvation of the soul?

One common interpretation of Rom 13: 1-7 is that Paul re-inscribes colonial values to colonial subjects (Sugirtharajah 1998: 20). Paul seems to allude that God and history are on the side of the Roman Empire. The only options left to the colonized is subordination or resistance. Paul seems to advocate support for the Roman Empire's political authority and offers no political strategy or solution for its liquidation. On the other hand, Elliot (2011: 64-65) argues that Paul should be read as more critical, challenging and antagonistic towards the Roman Empire. Drawing from the above two positions, the author sees Paul's position as both socially conservative and politically challenging towards the Roman Empire. This position is well supported by Wright (2004: 82-87), who says Paul's views on Romans 13: 17 represent a significant demotion rather than elevation of emperors; however, Paul is doing it in a wise way. Bhabha (1995: 206-209) refers to the way Paul is communicating as negotiating between cultural diversity and cultural difference. Charles (2009: 247) summarises this as a way to understand the different struggles that come to play in defining authority and subordination in a particular colonial situation. Hence in challenging his audience, Paul challenges the dominant elites' exercise of authority as guided by the good, and not the bad, as he does in Romans 13: 1-7.

A logical starting point for the analysis of Romans 13: 1-7 is apartheid South Africa where systemic and endemic violence, designed to create the theology of the empire, was embedded in the institutional superstructure and the institutional theology of the Dutch Reformed Church. This theology was rightly criticised by the Kairos Document of 1985. A colonial interpretation of Romans 13: 1-7 became an exemplar for other African dictators.

For many Christians across the world, Romans 13 is an unequivocal, unrelenting call for blind obedience to the State (Lamarquand in West and Dube 2000: 83, cited in Mukuka 2012). This was epitomized in South Africa where, for many years, the apartheid regime, bolstered by the colonial hermeneutics of the Dutch Reformed Church, used Romans 13 to justify their unfair treatment of the majority Black population, whose challenge was that of 
submission (Munro 1990). However, as early as 1967, Susan Rennie Ritner (1967: 17-37) pointed out the irony of the Church's position when it tried to build on the Christian message of brotherhood to buttress the apartheid regime.

It is somehow ironic to still find African leaders today who use the Bible against their own people. In 2008, Robert Mugabe once declared, 'Even Romans 13 says leaders are appointed by God. 'I am an image of God who appointed me to my current position' (The Daily News 2008.) Such a reading of Romans 13 has not always been unanimous. A similar stand was adopted by the second Zambian President, Frederick Chiluba, in the face of opposition to his religio-political decisions, especially from the leadership of the Zambia Episcopal Conference during the period 1991-2001.

\section{Acceptable Interpretation of Romans 13:1-7}

There have always been voices of dissent that question if every authority enjoys the divine right to obedience, or only those that excel in their responsibilities. In the context of Rom 13: 1-7, one's immediate problem is the injunction to be submissive to the ruling authorities. What do we understand by the term 'authority'? Are all authorities, including repressive and corrupt regimes, worthy of obedience? In the light of our understanding of authority and obedience to the state one needs to question whether the prevailing authority excels in its authority and therefore worthy of our submission. It is this interpretation that the researcher agrees with. Interpreters of Romans 13: 1-7 ought to use insights from the historical-critical method as a springboard for the newer tools of Biblical interpretation. Throughout the history of Christianity, totalitarian regimes have tried to legitimize an attitude of blind obedience and absolute servility towards the state by quoting this text, which compounded political gullibility among many Christians.

\section{Pentecostal Political Passivity}

Togarasei (2017: 21) describes Pentecostals Biblical interpretation as possible contributor to the pacification of the public in socio-economic and political affairs of Zimbabwe. He further highlights that Pentecostal Biblical interpretation led people to surrender everything to God and to describe everything as the will of God and allow the status quo to prevail. It is this Pentecostal stance regarding politics that the researcher refers to as political gullibility. Political gullibility among Pentecostal Churches, therefore, becomes the uncritical en- 
dorsement of and submission to exploitative and abusive powers that are preached in some Pentecostal sermons. Banana, as cited in Tshuma (2017), explains such naivety and unwarranted meekness by the Church during the armed struggle for independence when he asserts that the Church spent years preaching peace and forgiveness in the midst of war and vengeance, powerless love in a state of loveless power, obedience in a state of rebellion, and loyalty in a state of illegitimate authority. Thus, Church activism in the context of social disintegration and national polarisation demands a practical, socio-political and economic engagement with the relevant arms of governance and political players or parties in order to move towards a socio-political contract that will give birth to peace and democratic space for all. This type of message is alien to the vast majority of Pentecostal preachers who are busy trying to appease the powers that be, even in matters where there is gross abortion of justice and human rights abuse. This is why the article maintains that Pentecostal position in respect of the State's atrocities is shrouded in ambivalence and unwarranted neutrality, indicative of passivity, which is evidence of gullible political behaviour.

Pentecostal Churches, who herald as the largest denomination and have managed to recruit the literate and illiterate alike, have no choice but to move from the confinement of salvation of the spirit alone at the expense of mortification of the flesh, eschatological and other worldly approach to constructive critical engagement on socio-economic and political misfortunes. Pentecostal Churches cannot afford to sit back and watch while new governments take their own course without spiritual guidance. Pentecostal Churches' withdrawal from their prophetic role as the salt and light has given leeway to some politicians to shut Christians out of politics, telling them not to mix church with politics, since they found backing from the conservative biblical interpretation that seems to endorse these rulers blindly, citing Romans 13: 1-7. Today's Church must reject the lie and participate in the running of the nation (Guti 1994: 54).

Pentecostals are apocalyptic in their political understanding for their preaching regards political challenges as a passing phase guided exclusively by politicians, which in no time shall be a thing of the past. The message of hope and the call for resilience leaves everything to prayer, waiting for God to change the situation. People's hopes are pinned on God's time to change everything, while its members are subjected to economic and political strife. The Pentecostal response to these gross human rights abuses is conservative at the expense of the suffering masses, as if economic and political challenges 
exclude Pentecostal Christians. This position aligns with the view that most African Pentecostal churches are conservative by nature and enjoy a panAfrican agenda. They tend to support the status quo.

As argued by Raftopoulos and Mlambo (2008: 113), there was a time when the political climate itself warranted the silence of the church. This was when the church was confronted with the political intolerance of ZANU PF, which tried to establish its hegemony over autonomous civil institutions after independence, and churches avoided criticizing government openly; hence churches adopted the accommodationist approach to the state. During this era, the Church in this era was swallowed by the state or accommodated itself to the state. This was partly due to the brutality of the security forces and the natural peace-loving nature of the people of Zimbabwe. However, due to mounting social and economic pressures, churches could not stand it any longer; hence, critical engagement evidenced by some church-based organizations speaking prophetically against the status quo.

What explains ZAOGA's aloofness or political passivity around the 1980s, according to Maxwell (2006: 250), was the political climate punctuated by danger. ZANU PF guarded its legitimacy against opposition and any form of criticism. ZAOGA was a target because of its mass appeal. It had to protect itself; hence a lack of involvement in politics. The stance of ZAOGA distancing itself from politics was a calculated move, given the reigning political intolerance, though this ambivalence was at the expense of the masses. This position taken by ZAOGA is not unique to ZAOGA, but was used by many Zimbabwean individuals and faith-based organisations for safety. Politicians capitalize on this stance; hence they instil fear in people in order to weaken any form of protest. That is why passivity is interpreted by many as gullibility.

\section{Pentecostal Political Consciousness}

The kind of Pentecostal consciousness raised by Guti (1994: 63) in his book, The Church and Political Responsibility, clearly expresses the politically consciousness gospel. It talks of the responsibility of the Church in politics; that is, the need for the Church to be involved in the running of the government through the guiding authority from God. For Guti (1994), preaching alone without participating in the development of a nation can only help spiritually, while people live in poverty, without financial resources to spread the gospel. 'That is why politicians are not bothered about indigenous churches because they do not have a realistic approach' (Guti 1994: 49). It means that children 
cannot get medicine and teachers do not teach. ZAOGA has even conducted 'Healing the Nation' crusades, preaching the gospel of reconciliation to survivors of political violence. The message of justice and peace is taken to the people and even to the State House. In his book, Guti writes and preaches political consciousness, but practically speaking, the stance of the Church in politics is still minimal. There is yet a need for an effort to put the Founder of Zimbabwe Assemblies of God Africa Forward in Faith's theory into practice.

However, due to the economic meltdown in Zimbabwe since the year 2000, ZAOGA had a leeway through the doctrine of talents. According to Maxwell (2006: 202), the doctrine of talents inculcates the spirit of industriousness and creativity where women in particular are encouraged to prosper in the Church through hard work. Women engage in selling an assortment of wares and numerous small items and goods in the spirit of promoting self-reliance, in the wake of desertions by their husbands in response to the rising cost of living.

Through their agencies and in faith-based organisations like EFZ, ZCBC, and ZCC, Pentecostal churches have participated in the democratization of the country. Through these platforms churches, both mainline and Pentecostal, pledged to use their global and international connections to help the government build bridges among and between Zimbabweans and the international community (ZCBC, ZCC \& EFZ 2006: 43). However, this effort by churches is not coming to fruition since some Christian leaders are aligned with the state, benefiting from the status quo. Thus, Zimbabwe's socioeconomic and political challenges are indicative of a wedge of division that separates the State from the church's guidance; hence this discussion to reconsider the detrimental effects of such a separation.

In 2018 and at a ZCC Conference at Arupe Jesuit University, Taringa asked how proper it was for the Church to try and offer solutions to the political problems of the State and later come up with a political party. He further attested that, this is the dilemma of the Church. Taringa concluded his 2018 presentation by citing Martin Luther King Jr's view that the belief that God will do everything for humanity is untenable, because that is not faith, but superstition.

\section{Findings}

Pentecostal movements have never formally spelled out their approach to scriptures, such that Pentecostal hermeneutics is still a burning issue in the $21^{\text {st }}$ century. Pentecostals love the Bible but the majority seem to be restricted to a 
literal interpretation of the text. They seem not to be conscious of the historical critical methods; hence they fall into the detour of eisegesis (reading one's ideas into the text) instead of exegesis (drawing meaning from the text). This is evidenced in a number of Pentecostal church leaders who spoke on behalf of their churches, and individual church leaders who openly showed their allegiance to the government, irrespective of all glaring misgivings. Tshuma (2017) castigates these as a curious breed of 'Men of God' who are peddling party political propaganda in the name of God. These political activist cadres masquerade as Christians and purport to preach the virtues of forgiveness, national healing and peace, when in fact all they are doing is covertly conveying party-political messages to an unsuspecting clergy and general membership of the Church, which turns the follower into the pitfall of gullibility. This can be viewed as an infiltration of churches by using divideand-rule tactics whereby party politics are disseminated to the congregants by a religious leader on behalf of the politicians. The followers, due to the respect owed to the charismatic leader, abuse the pulpit to further his/her interests. The attitude of religious leaders (Pentecostal) who shower the powers that be with blind eulogies, reiterating their divine appointment using literal interpretation of Romans 13: 1-7, mislead, dupe and trick the majority of Pentecostals into political passivity. The issue at stake is not that leaders who execute their duties with people at heart should not be praised, but Christian leaders are now blind nationalists divided alongside partisan politics and promoting that stance to members as the will of God. This attitude is what is imparted to the flock or congregants to support ungodly authority faithfully as Divine will spiced with a biblical flavour of a misinterpretation of Romans 13: 1-7. This has led to Tshuma's comment that 'Party politics has found its way into the pulpit, bringing the name of the Church into disrepute', hence swaying most Christians into gullible behaviour; thus promoting the political interests of the religious leader as if it is the will of God (Tshuma 2017).

However, Pentecostal leaders cannot be painted with one brush, for there was a minority voice from Pentecostal leaders who opposed the gross abortion of justice by the government; hence they clamoured for justice. Guti (1994: 11) reinforces the need for positional change by the Church on a onesided salvation gospel when he explains that: The focus of the church and its theology has been pre-occupied with heaven. It needs to be changed, because once you receive Jesus as your personal Saviour and be born again; walk in the fear of the Lord, heaven is yours. With this move some Pentecostal voices are now being heard. 
According to Guti (1994: v), church and government should work together, as exemplified by the Old Testament's theological narration: As in the past the nations had a head of state who ruled under the direction of God through the prophet. It was a prophet who would be used by God to warn the nation when it sinned. He would go to the head of the state to inform him what God was saying and he would heed the warning. This prevented the famine, starvation and many other disasters that might befall the nation, as the leader and nation humbled themselves before God as in 2 Chronicles 7: 14. However, if they rebelled against the warning of God, then catastrophes would befall them.

It is also important to note that Jesus Christ himself also dealt with gullible behaviour in Matthew article 4. The devil tried to trick Jesus by quoting scriptures. 'Change stones into bread ----' but Jesus refused to listen and believe the devil's tricks. Therefore, non-gullibility in dealing with the devil is a quality attributed to Christ, as reflected in Matthew 4. Christians must take a leaf from their Messiah on how to deal with religious gullibility.

\section{Conclusion}

Pentecostal Biblical interpretation leads people to surrender everything to God, therefore allowing the perpetuation of the status quo. Pentecostals are facing serious challenges of a belief that it is rebellious to question teachings and practices of authority figures. The Pentecostal belief that the Lord's anointed are not touched, failure to differentiate between anointing and crowd control techniques as well as the difference between presence of God and goose bumps are areas that Pentecostal members need exercise caution. Propensity of exaggeration is high in the Pentecostal leaders. Pentecostal growth in Africa is creating a standardized view of the world that will function as a sort of imperialism, by associating the personal political interests of the Pentecostal leaders with those of God. They impart this to followers as dreams or visions received from God; hence, Pentecostal followers accept the stance blindly, which turns into gullibility.

Pentecostal politics promote a wave of 'new Christendom' in Africa whereby Pentecostal adherents are attracted to the dream of converting the ruler, or of electing one of its own members as president, seeing this as the height of its political aspirations and as panacea for the problems of the country. There is little understanding of politics as a system; instead, there is the recurrent 'messianic' hope in an 'evangelical' or 'born-again' president, 
and a belief in the possibility of the 'people of God' exercising power in an unambiguously positive way.

Pentecostals adhere to triumphalist theology; this traditionally apolitical religious community is unable to see itself as one political actor amongst many; it sees itself as the most important. Something along those lines has already occurred in Zambia, where a Pentecostal president declared the country to be a 'Christian nation' and performed a ceremony to cleanse the presidential palace of nefarious spiritual influences left over from the previous occupant, but in the end he had to leave power immersed in accusations of corruption and abuse of human rights. The case of Zambia and other examples from Africa and Latin America show Pentecostals to be very susceptible to the prevailing political culture in each national context. The idea of spiritual warfare ascribes a country's problems to the fact that the wrong people are in power, and we are the right people. There is no concept of political apprenticeship, nor of painstaking construction of a movement over many years, through education and institutional development.

However, for the long and more diffuse process of democratic consolidation, Pentecostals might be more useful, because they are anti-fatalist and teach ordinary people to exercise leadership in public spaces. Pentecostals, therefore, do not fit into the negative stereotypes of being dangerous for democracy, potentially violent. However, neither do they fit their own cherished self-image as carriers of political blessings for their countries.

\section{Recommendations}

The article recommends that Pentecostal biblical interpretation should not only be limited to literal interpretation which leads to eisegesis, but may use historical critical methods that lead to exegesis. Pentecostal churches should have tremendous spiritual, social, economic and political influence on the mundane life of Zimbabweans since they claim a mass following in the area of evangelization. Their excellence in organizing national prayers and national crusades as evangelistic methods must carry with them political consciousness as relevant message.

The article further recommends that Christians, in dealing with gullibility, must follow Jesus' example who, in Matthew 4, refused the devil's appeal to scriptures without sanity.

The Pentecostal churches need to be united in themselves and join other faith-based organisations to counter political divisions. Their unity must 
transcend party politics, as it includes people from all parties and stand for the good of all Zimbabweans. Pentecostal Church leaders should guard against being manipulated by politicians and always be neutral in their engagements. Pentecostal churches that herald themselves as the biggest and fastest-growing churches in numbers must also grow in activism, so that their biblical interpretation influences the socio-economic and political landscape. The respect owed to Pentecostal leaders by their followers as voice of God among the people must be utilized to influence congregants into political responsibility rather than political passivity.

\section{References}

Anderson, A.H. 2010. Varieties, Taxonomies and Definitions. In Anderson, A.H. (ed.): Studying Global Pentecostalism: Theories and Methods. Berkeley: University of California Press, Ltd.

https://www.academia.edu/6068798/Global_Pentecostalism Charismatic _Movements_and_Independent_Churches_Christianity_Shifting_South wards_Historical_Overview

Bhabha, H.K. 1995. Cultural Diversity and Cultural Differences. In Ashcroft B., G. Griffiths \& H. Tiffin (eds.): The Post-Colonial Studies Reader. London: Routledge.

https://books.google.com.gi/books?id=zcpiQwtw4hMC\&printsec=frontc over\&rview $=1 \# \mathrm{v}=$ onepage $\& \mathrm{q} \& \mathrm{f}=$ false

Borg, M.J. 2002. Reading the Bible again for the First Time: Taking the Bible Seriously but not Literally. San Francisco, CA: Harper San Francisco. https://www.amazon.com/Reading-Bible-Again-First-

Time/dp/0060609192?asin=0060609192\&revisionId=\&format=4\&depth $=1$

Charles, R. 2009. Hybridity and the Letter of Aristeas. JSJ 40: 242-259.

Chimuka, T.A. 2017. The Threat of Gullibility: Faith and Christian Behaviour in Southern Africa. Oral History Journal of South Africa 5,1: 49 - 63. Available at:

https://journals.co.za/content/journal/10520/EJC-f2c6f811e (Accessed on 15 June 2018).

Clifton, S. 2009. Empowering Pentecostal Women. Asian Journal of Pentecostal Studies (AJPS) 12, 2: 171-179:

Available at: www.app.edu; (Accessed on 12 June 2018.) 
Creswell, J.W. 2014. Research Design. London: Sage Publications Ltd.

Elliot, N. 2011. The Arrogance of Nations: Reading Romans in the Shadow of Empire. (Paul in Critical Context Series.) Minneapolis: Fortress Press. https://www.bibleandcriticaltheory.com/issues/vol7-no1/vol-7-no-12011-review-of-neil-elliott-the-arrogance-of-nations-reading-romans-inthe-shadow-of-empire-paul-in-critical-context-series-minneapolisfortress-press-2008/ (Accessed on 13 July 2018.)

Freston, P. 2014. Religion and Politics in Global Context. Ontario, Canada: Wilfrid Laurier University.

Friedrick, K. 2017. The Progressive Pentecostal Conception of Development within an African Context of Poverty. Stellenbosch Theological Journal (STJ) 3,1. Available at:

http://www.scielo.org.za/scielo.php?script=sci_arttext\&pid=S241394672017000100010

(Accessed on 17 September 2018.)

Greenspan, S. 2009. Annals of Gullibility: Why we Get Duped and How to Avoid it. Connecticut: Praeger Publishers.

Greenspan, S., G. Loughlin \& R. Black 2003. Credulity and Gullibility in Persons with Mental Retardation. In Glidden L.M. (ed.). International Review of Research in Mental Retardation 24: 101-135.

Guti, E.H. 1994. The Church and Political Responsibility. Harare: EGEA Publications.

Guti, E.H. 1997. History of ZAOGA Forward in Faith: The Book of Remembrance. How it Began and Where It is Going. Harare: EGEA Publications.

Hayes, J.H. \& C.R. Holladay 2007. Biblical Exegesis. West Minister: John Knox Press.

Kairos Document 1[985] 1985. Theological Comment on the Political Crisis in South Africa. London: Catholic Institute for International Relations (CIIR).

Kallas, J. 1965. Romans XIII. 1-7: An Interpolation. Available at:

https://bradlittlejohn.com/2010/09/30/2010930romans-131-7-an-

interpolation-html/

(Accessed on 18 August 2018.)

Käsemann, E. 1980. Commentary on Romans. London: SCM.

Lamarquand, G. 2000. New Testament Exegesis in (Modern) Africa. In West, G.O. \& M.W. Dube (eds.): The Bible in Africa: Transactions, Trajectories, and Trends. Leiden: Brill 
Mukuka T. 2012. Reading/ Hearing Romans 13:1 - 7 Under an African Tree: Towards a Lectio Postcolonial Context Africana. Neotestamentica 46,1: 105-138. Available at:

https://www.jstor.org/stable/43048847

(Accessed on 18 August 2018.)

Lobkowicz, N. 1964. Karl Marx's Attitude on Religion. The Review of Politics 26,3,July: $319-352$.

https://www.jstor.org/stable/pdf/1405231.pdf?refreqid=excelsior\%3A9b 614d96283e992279180553764be9f2

(Accessed 17 September 2018.)

Maxwell, D. 2006. African Gifts of the Spirit: Pentecostalism and The Rise of a Zimbabwean Transnational Religious Movement. Harare: Weaver.

McKinnon, A.M. 2005. Reading 'Opium of the People': Expression, Protest and the Dialectics of Religion. Available at:

https://doi.org/10.1163/1569163053084360

(Accessed on 19 October 2018.)

Michaelian, K. 2010. In Defense of Gullibility: The Epistemology of Testimony and the Psychology of Deception Detection. Synthese 176: 399-427. DOI: 10.1007/511 229-009-9573-1.

Miller, E. \& Y. Tetsunao 2007. Global Pentecostalism: The New Face of Christian Social Engagement. Berkeley, CA: University of California Press.

Munro, W. 1990. Romans 13:1-7: Apartheid's Last Biblical Refuge. In Nanos, M.D. (ed.): The Mystery of Romans: The Jewish Context of Paul's Letter. Minneapolis: Augsburg Fortress.

Origgi, G. 2008. Trust Authority and Epistemic Responsibility. Theoria, Universidad del Bio-Bio 23/1, 61: 35-44.

Osborne, R. 1992. Philosophy for Beginners. Village Station: New York.

Raftopoulos, B. \& A.S. Mlambo (eds.). 2009. Becoming Zimbabwe: A History from the Pre-Colonial Period to 2008. Harare: Weaver Press.

Recanati, F. 2004. Literal Meaning. Available at:

https://www.researchgate.net/publication/36734770 Literal Meaning/cit ation/download

(Accessed on 17 August 2018.)

Ritner, S.R. 1967. The Dutch Reformed Church and Apartheid. Journal of Contemporary History: Church and Politics 2,4: 7-37.

Shafranske, L.R. 1996. Cognitive-behavioural Therapy and the Religious Person. In Shafranske, E.P. (ed.): Religion and the Clinical Practice of 
Psychology. Washington, DC: American Psychological Association. Available at: http://dx.doi.org/10.1037/10199014

(Accessed on 15 August 2018.)

Shafranske, E.P. (ed.). 1996. Religion and the Clinical Practice of Psychology.

American Psychological Association. Available at:

https://doi.org/10.1037/10199-000

(Accessed on 17 August 2018.)

Spivak, G.C. 1999. A Critique of Postcolonial Reason: Toward a History of the Vanishing Present. Cambridge MA: Harvard University Press.

Stanley, S.C. 2007. Wesleyan/ Holiness and Pentecostal Women Preachers: Pentecost as the Pattern of Primitivism. In Yong, A. \& E. Alexander (eds.): Philips' Daughters: Women in Pentecostal-Charismatic Leadership. Eugene: Pickwick Publishers.

Sugirtharajah, R.S. 1998. Asian Biblical Hermeneutics and Postcolonialism: Contesting the Interpretations. Sheffield: United Bible Societies.

Taylor, S.E., L.C. Klein, B.P. Lewis, T.L. Gruenewald, R.A.R. Gurung \& J.A.

Updegraff 2000. Behavioural Response to Stress in Females: Tend-andbefriend not Fight-or-flight. Psychological Review 107: 441-429.

The Daily News. 09 December 2013.

Togarasei, L. 2013. Pentecostal Churches and Politics in Zimbabwe's Turbulent Years (2000-2008). In Chitando E. (ed.): Prayers and Players: Religion and Politics in Zimbabwe. Harare: SAPES Books.

Togarasei, L. 2017. Assessing the Place of Pentecostal Biblical Interpretation in Zimbabwe's Socio-Political and Economic Affairs. In Chitando E., F. Machingura \& L. Togarasei (eds.): Pentecostalism and Human Rights in Contemporary Zimbabwe. Cambridge: Cambridge Scholars Publishing.

Tshuma, V. 2017. Beyond the Pulpit Gospel: An Overview of Pentecostal Churches' Engagement with Socio-Economic and Political Issues in Zimbabwe - A Case of ZAOGA FIF and Word of Life. In Chitando E., F. Machingura \& L. Togarasei (eds.): Pentecostalism and Human Rights in Contemporary Zimbabwe. Cambridge: Cambridge Scholars Publishing.

Wright, N.T. 2004. Paul for Everyone: Romans, Part Two. Articles 9-16. London: SPCK

Young, E. 2010. Challenges to Conceptualising and Actualising Culturally Relevant Pedagogy: How Viable is the Theory in Classroom Practice? Available at:

https://doi.org/10.1177/10022487109353775

(Accessed on 28 August 2018.) 
Henerieta Mgovo

ZCBC, ZCC \& EFZ 2006. The Zimbabwe We Want: Towards a National

Vision for Zimbabwe by the Churches of Zimbabwe. Harare: Benaby Printing and Publishing.

Henerieta Mgovo Department of Philosophy and Religious Studies Great Zimbabwe University Masvingo henerietamgovo@yahoo.com 